\title{
TENDENCIES AND FACTORS OF REGULATION OF DEVELOPMENT IN LATVIAN BANKING SYSTEM
}

\author{
Alexander Masharsky ${ }^{1}$ \\ Baltic International Academy (Latvia)
}

\begin{abstract}
The aim of the paper is to study the influencing factors and to identify the ways of improving the effectiveness of regulation in the Latvian Bank system (LBS). Basing on the systemic comparative and logical analysis data of the efficiency of regulation in different stages of LBS development article demonstrates that its key factor is the level of business ethics and professionalism of major shareholders and top management of the banks, but the main directions of improving its efficiency is an increase of the role of content approach to control in comparison with the formal approach.

KEYWORDS: banking system, factors, features, regulation, tendencies.
\end{abstract}

JEL CODES: G 280, G010, G210.

Introduction

Qualitatively new level of risks of modern financial markets shifts the priorities of regulation of the financial and banking systems from growth to sustainability.

One of the key factors for sustainable development of the national banking system, along with macroeconomic policy, financial infrastructure, market discipline, the level of business ethics and professionalism of key shareholders and top managers, is the efficiency of the bank management.

Prudential (reasonable) regulation and supervision are key factors in the stability of the banking and financial systems.

The main lesson of the global financial crisis is to recognize inefficiencies in the current world system of financial regulation and the need for radical reform.

In 2010, the U.S. adopted and signed into the law "Dodd-Frank Wall Street Reform and Consumer Protection Act", which determines the most radical, since the Great Depression of the 1930th, institutional reforms of the U.S. financial system and provides:

- withdraw unfathomable parts of the financial sector from the shadows;

- express prohibition of saving the banks with taxpayers' money;

- measures to protect consumers of financial products and services from unscrupulous financiers. The main purpose of the reform is to prevent a recurrence of the financial crisis in the U.S. covered the entire world.

Similar transformation steps in financial regulations also have taken other developed countries. In January 2012 work started the European Systemic Risk Board, until January 1, 2014 the European Central Bank

Alexander Masharsky - Baltic International Academy (Latvia), Faculty of Financial Management, prof., dr. oec. Scientific interests: Bank Risk Management, Bank Capital Adequacy, International Financial Market

E-mail: a_mash@inbox.lv

Tel.: +371 29546772 
(ECB) will become a single body of supervision overall six thousand banks in the Euro area. There has been taken the law on restricting the bank bonuses within the double amount of bankers' annual salary; the EU banks are presupposed to separate the significant part of their trading activities into the specified capitalized units and the requirements of the Basel Committee on capital have been tightened.

Although Latvia's accession to the European Union and its financial regulatory system working according to all European standards, the consequences of the crisis for the country were among the most severe in the EU - $25 \%$ drop in GDP in 2008-2012 g.g., more than 84.4 thousand people went abroad in 2009-2010, mainly for the reason of failure to timely pay the previously taken mortgages and consumer loans.

Despite the profitability recovery in Latvian banking system (LBS) and in CIS and high, compared to other EU countries, GDP growth at 5,6 \% in 2012 - crisis for entrepreneurs and households, according to the experts are far from complete.

At the same time, such countries as Canada and Australia easily overcame the effects of the crisis through more efficient Financial Regulation than other countries (Stiglitz, 2010: 389).

The lag in the development of financial markets in CIS countries weakened or completely eliminated the crisis increasing factors, like large-scale mortgage lending and securitization of assets, which have played a negative role in the banking systems of developed countries.

These facts show the importance of accounting for improved regulation of the financial and banking systems of national peculiarities of Latvia.

Problem: incomplete use of reserves for increasing the effectiveness of the regulatory system as a result of the introduction of international standards without sufficient regard for the features of the Latvian banking system (LBS).

Purpose: to identify ways to improve the effectiveness of regulation in the LBS.

Object: LBS regulatory system.

Tasks:

- Trends and factor analysis of the LBS regulation development;

- Analysis of the effectiveness of LBS regulations during the current crisis and international regulatory standards reform;

- Identifying ways to improve the effectiveness of regulation in the LBS.

Research methods: logical and statistical analysis, generalization, cross-country comparisons, expert assessments.

\section{Regulation of Banking System: Definition}

In scientific and regulatory sources external and internal regulations of banks are identified by various terms - "regulation", "prudential regulation", "supervision", "financial control", "external and internal control".

The banking regulations is taken as creation of an appropriate legal framework: the development and adoption of laws, regulating the activities of banks, instructions, directives regulating and specifying the bank operations; the supervision of the bank means monitoring the processes at different stages of the banks functioning: the creation of new banks and their agencies; banks activities, banks reorganization and liquidation.

Regulation and supervision of banking activities are inter-related and complementary activities and further are considered tantamount (Stephen Frost, 2006: 495).

At the same time, in the world accepted conceptual basis of the internal control organizations, developed by a working group under the patronage of the Committee of Sponsoring Organizations of the Treadway Commission, terms such as "financial control" and "external control" are not used, neither they are used in the developed on its basis the broader concept of risk management (COSO, 1992). 
The term "financial control" is also missing from recommendations of the Basel Committee on Banking Supervision, where internal control is defined as a process carried out by the Board of Directors, management and employees at all levels, which is constantly moving among all levels within the bank (BCBS, 40).

An identical definition of internal control in the credit institution is given in the Guidelines of the Basel Committee on Banking Supervision.

The term "financial control" has been widely represented in the researches of centralized economy period and during the transitional period to a market economy, and generally identified with a state-control, until the period of introduction and usage of international language and worldwide accepted terminology, in Latvia and CIS countries the term got virtually identical meaning to the term "control" and is addressed both to the organization level and to the higher levels. In centralized economy countries' form of organization and purpose of financial control were mostly subordinated to the interests of states, had global and ubiquitous nature and mainly persuaded fiscal objectives.

The term "external control", although missing from the conceptual database of the organization risk control and management, by contrast, is widely used in the regulations governing the national banking authorities and special literature (COSO ERM, 2004).

Therefore, below, the term "external control" of the banks is understood as identical to the terms "regulation" and "supervision" of banking activities.

To days' market changes under the influence of globalization, information and financial innovations have made modern prudential regulations be risk focused.

External and internal audit in the modern risk - oriented control systems of the bank solves much wider range of problems, than just the evaluation of the reliability and information disclosure in annual financial statements. It became an instrument of audit and assessment of the adequacy and effectiveness of risk management in the banks.

Modern supervisory process aims to assess the bank risks and is similar to the information's financial analysis, the effectiveness of which depends on the accuracy of financial information and the assessment of corporate governance (Van Greuning, Bratanovic, 2003: 23).

Therefore, a modern banking supervision, along with the methodology of internal and external control of the banking practice, constitute internal and external audit (Barltrop, McNaughton, 1994: 193).

\section{Factors and features of LBS development and regulation.}

Latvia's rapid advancement on the path of market reforms and deeper integration into the EU, geographical location and the nature of historical ties with the East and the West helped to high level development of LBS systems and its regulation.

The ratio of bank assets to GDP in Latvia at the end of 2012 was $128 \%$, which is higher amongst new market economies of post-Soviet states and Eastern European countries, except for Slovenia (Figure 1).

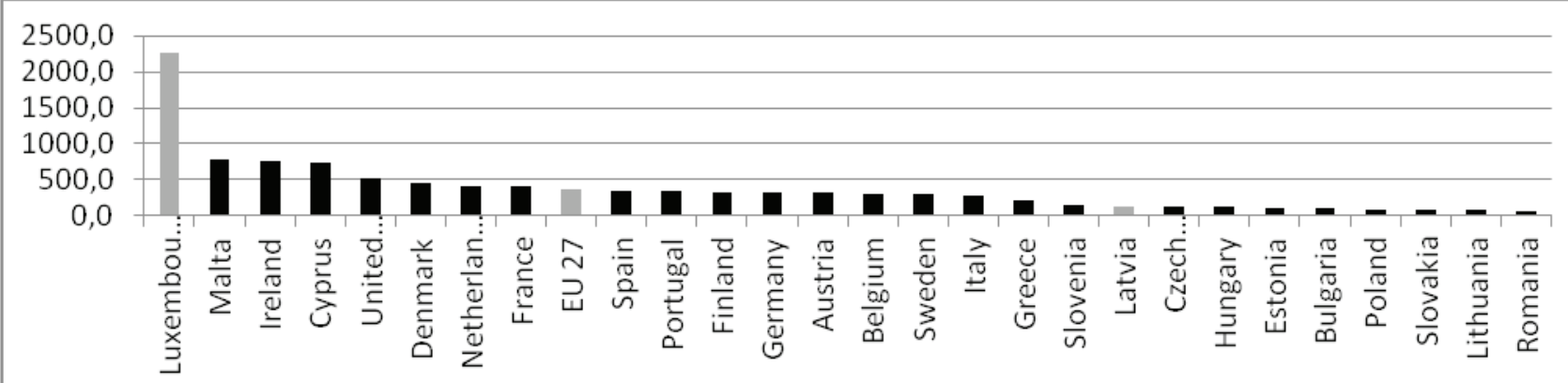

Figure 1. The ratio of bank assets to GDP (at the end of 2012, \%)

Source: ECB, Eurostat, calculated by Bank of Latvia 
LBS is represented by 20 banks and 9 branches of foreign banks and is characterized by:

- large-scale dollar transactions from the East;

- a high proportion of non-resident deposits $-49 \%$ of total deposit amounts (at the end of February 2013) in Latvian banks;

- a high proportion of non-residents paid-up capital - 72.3\% (as of end of March 2012) in Latvian Banks.

These data show that in the Baltic region Latvia is a regional financial center with well-developed financial and banking infrastructure.

The political priorities of Latvia, Lithuania and Estonia of ultimate integration to the EU have led to the banking systems input domination from the banks controlled by foreign capital. The dominant position among those occupy four Nordic banks: "Swedbank" and SEB (Sweden), DNB (Norway) and a "Nordea Bank" (Finland). From 1,669 bil. Lats (2.394 billion euro) of bank's paid-up capital in Latvia 45.8 \% is owned by Sweden.

Location and a strong historical ties with the East made range of countries represented capital in Latvian banks broader and reduced overall the share of the above-mentioned banks in the Latvian market; in total the loan portfolio is $64.7 \%$, while in Lithuania $-77,6 \%$ and $88.7 \%$ in Estonia. The share of banks with a national capital majority in Latvia $-19.0 \%$, Lithuania $-4.3 \%$, Estonia $-3.1 \%$.

In Latvia, the banking activities are regulated by the Law on Credit Institutions (1995); the credit institutions, apart from banks, include other financial establishments emitting electronic money.

With the adoption of the law On the Financial and Capital Market Commission (FCMC) in 2001, supervision of banks, as well as all other sectors of the financial market is provided by a single integrated mega-regulator, which also took over the functions of different sector regulators, including the Office for the supervision of credit institutions of the Bank of Latvia, the Securities Market Commission and the State Inspectorate of the insurance market.

Along with the FCMC the system of external control of Latvian banks also includes Bank of Latvia, regulating the amount of the banks required reserves and providing the reliability of the national payment and settlement systems, and the Institute of Independent Auditors (Certified Auditors). Significant role plays Latvian Commercial Banks Association, founded in July of 1992, which aim is to promote and strengthen the development of the Latvian banking system.

In accordance with the requirements of the European Union from 1997, Latvia has the Deposit Guarantee Fund with a maximum guarantee amount of 100,000 euro (2011).

The internal control system (ICS) act in accordance with the standards of the Committee of Sponsoring Organizations of the Treadway Commission (Committee of Sponsoring Organizations, COSO) and the recommendations of the Basel Committee on Banking Supervision and includes three main functions:

- risk management;

- provision of compliance control;

- internal audit.

Geographical and historical features of Latvia hold the risk of money laundering of criminal proceeds and financing of terrorism, as one of the key compliance risks.

3. Efficiency of risk management on different stages of LBS development and its regulation

Development of the system of regulating banks in Latvia was mostly determined by phased transit to European standards of regulating and the lessons of banking crises of years 1995, 1998 and 2008.

Crisis of 1995 demonstrated all contradictions of the period of primary capital accumulation and market reforms when inevitable lack of competence of bank management and authorities of Bank of Latvia were 
combined with ways of enrichment, condemned from ethical point of view but corresponded to the legal framework; moreover, the direct fraud was also implemented. These factors created conditions for crisis, facilitated by sharp growth of crediting on the basis of high interest rates for attractive deposits.

During this crisis the number of banks decreased from 61 in year 1994 to 55 in year 1995; this amount included the biggest bank in Latvia which had obtained the very first license - "Baltia" Bank.

The crisis also demonstrated the inefficiency of toughening and formal copying the western standards under the conditions of forming the market system of regulation. This fact can be exemplified by the standard of $10 \%$ of the banking capital sufficiency; then it was decreased to the level of $8 \%$, corresponding to the international standards. Another example is employment of standards of short-term (below 1 year) and longterm (more than 1 year) liquidity, since even the banks followed these two standards successfully, became insolvent.

As a result, the period of assessment of bank liquidity standard was reduced to 30 following days.

The management of Bank of Latvia manifested its position in evaluating its role in coming crisis by assignment the top manager of Security Service of Bank of Latvia on the position of Department of Banks Control and Coordination.

The crisis of year 1998 induced by excessive investments of Latvian banks into government bonds of Russia and other CIS countries financed by "pyramid" principle, resulted in decrease of banks number from 32 in year 1997 to 28 in year 1998, including the insolvency of the biggest bank in Latvia - Riga Commercial Bank.

Latvia as a EU member state implements the whole package of ways of regulating the European banks including the requirement to the bank capital of international standards Basel-I and Basel-II oriented on protection from individual risks on the basis of both standard and advanced models; the differentiated mode of supervision depending on significance, transparency, complexity of operations and regulatory discipline; starting with year 2019 further toughening of requirements towards capital is presupposed for protecting the LBS from system risks on the basis of Basel-III standards.

In year 2012 the position of Director of risks affairs was introduced into the structure of bank management and the opportunity of organizing the Risks Committee as a part of Council was provided; it was done in correspondence with risk profile of the bank.

Although the crisis of consumer and mortgage lending of 2008 induced by crisis of mortgage lending in the USA info 2007 did not resulting reducing the number of banks in Latvia, but for Latvia it was one of the most difficult in the EU.

The milestone event for crisis was the procedure of nationalization of the system-forming bank Parex in year 2008; the diagnosis for this bank changed from "stable" to "critical" during one day. The insolvency of Parex Bank was induced not by lending problems but by unsuccessful 1 investments in securities; according to the experts' opinion, these investments were done on the purpose to increase the profitability of the bank and its value for selling the bank to the strategic investor.

Insolvency of Kraibanka (in 2012) was mentioned after opening in the bank the suppression of the fact of blocking the amount of about $49 \mathrm{mln}$. EUR on the correspondent accounts in foreign banks.

After taking the supervision of the banking activities from stockholders of Latvijas Krajbanka to FCMC at here were taken away $86 \mathrm{mln}$. LVL.

The Parliamentary Investigation Commission concluded that the measures taken by Supervisory Commission for providing the sufficiency of Latvijas Krajbanka capital were not efficient enough, while the denial to present the own assessment of personality of the principal investor was official negligence resulted in extremely negative effect (Skudra, 2012: 467).

The investigation of the degree of responsibility of FCMCresulted in resignation of its top management.

The State Bank Latvijas Hipotēku un Zemesbanka is in a difficult situation; its commercial part was transferred into the ownership of Swedbank, and according to informal information, this procedure brought $40 \mathrm{mln}$. LVL of losses. Nevertheless, the top management of the bank earned about twice more last year. 
Accordingly, in spite of implementation of the EU standards in the area of risk-management and the experience of two crises of years 1995 and 1997-1998, the LBS and customers of banks and economy in total suffered significantly with crisis in 2008; the expenses of banks for the development of the system of an internal control as a result of current reforming the system of international regulation are inadequate to the obtained results; it happened due to the formal approach to their implementation by both regulators and banks.

4. Stages of Developing the System of Controlling the AML/CTF within LBS and assessment of its efficiency

The role of Latvia as regional financial center is comprehensively seen in the flows of foreign capital passing Latvian financial and banking system.

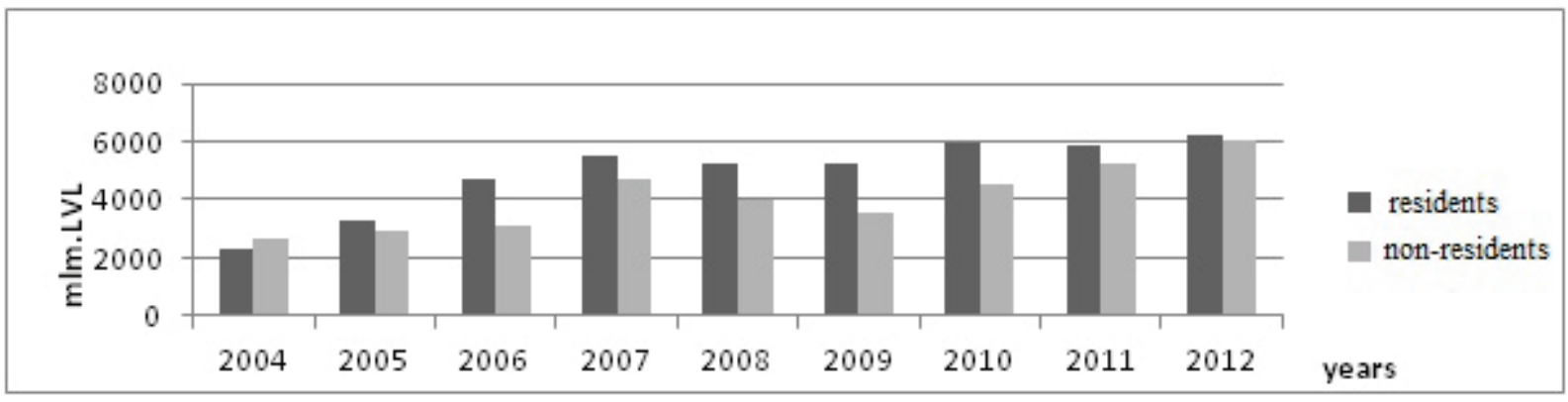

Figure 2. Dynamics and share of deposits of non-residents in the banks of Latvia, mln. LVL

Source: http://diena.lv/lat/business/hotnews/finance/eksperts_dati_par_nerezidentu_noguldiijumiem_buutiski_ kontekstaa_ar_finanshu_pakalpojumu_eksportu

Starting with year 2012, the inflow of deposits into the banks of Latvia from people living outside the EU is $\$ 1.2$ billion. The amount of non-residents' deposits on the banking accounts in Latvia increased to $\$ 10$ billion and takes about $50 \%$ of aggregate amount of deposits, while in Switzerland the amount of nonresidents' deposits is about $43 \%$ of total deposits, attracted by Swiss banks. WMF explain it by the fact that the investors from CIS mainly pull their funds from European Economic Area where the banks have difficulties, especially from Cyprus.

These facts demonstrate the special importance for LBS the efficiency of anti - money laundering and counter-terrorism financing (AML/CTF).

The principal stages of development of AML/CTF system are as follows:

- Adoption of Law on AML/CTF in1997.

- Organizing the Service of AML/CTF in1998 (controlling service, acting under public prosecutor's office supervision).

- In 2001 FCMC begins inspection of the Systems of Internal Control over banks.

- In 2005 the Council on AML/CTF was organized, and the President of Cabinet of Ministers was elected as its chairman.

- In 2007 the Committee on Development of Financial Sector was organised; it s connected with coordination and perfection of cooperation between the governmental and private organisations in AML/CTF area.

- In 2008 the Third Regulation of the EU on AML/CTF was approved. Its principal task is determining the real beneficiary.

- On 27.08.2008 FCMC approved the requirements towards the credit organizations on intensive supervision over the customers transactions.

One of the latest innovations on AML/in 2012 is the new method of checking the market members including visiting them by so called is Mystery Shopper, all over the world supposed to be one of the most efficient methods of controlling the actual practice of servicing the customer. The specially trained people 
Mystery Shoppers are employed for this operation; they implement the control function from the potential customers and report in details about the results of their investigation.

Since the evaluation of costs and benefits (CB) of AML/CTF isa rather complicated task and its scale is correlated with the scale of ML/TF, CB value should be evaluated by employment of qualitative valuation, based on inaccurate data and indirect indicators of ML/TF (FATF/OECD, 2008).

The data of Figure 3 show a sharp decrease of the number of reported unusual and suspicious transactions to Control Service of General Prosecutor of Latvia after the crises beginning, but from 2010 the level of their number remained practically unchanged (Figure 3).

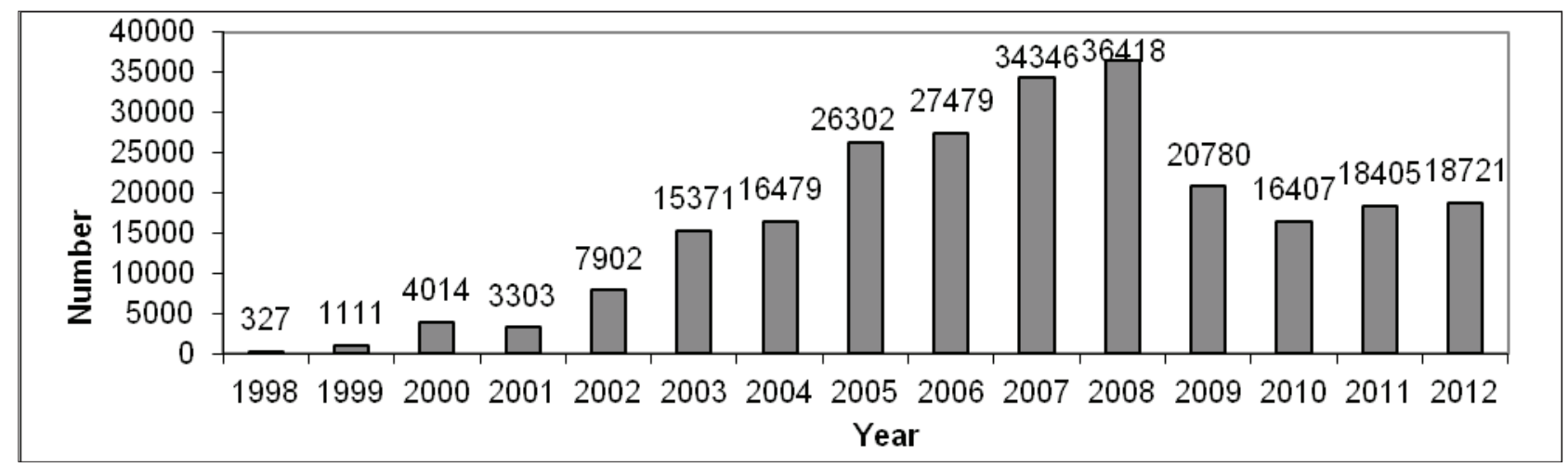

Figure 3. Number of reports on unusual and suspicious transactions

Source: Composed by the author according to http://www.vdi.gov.lv/lv/

At the same time, the number of initiated and brought to court cases does not correlate with the dynamics of reports and does not show significant decrease (Figure 4).

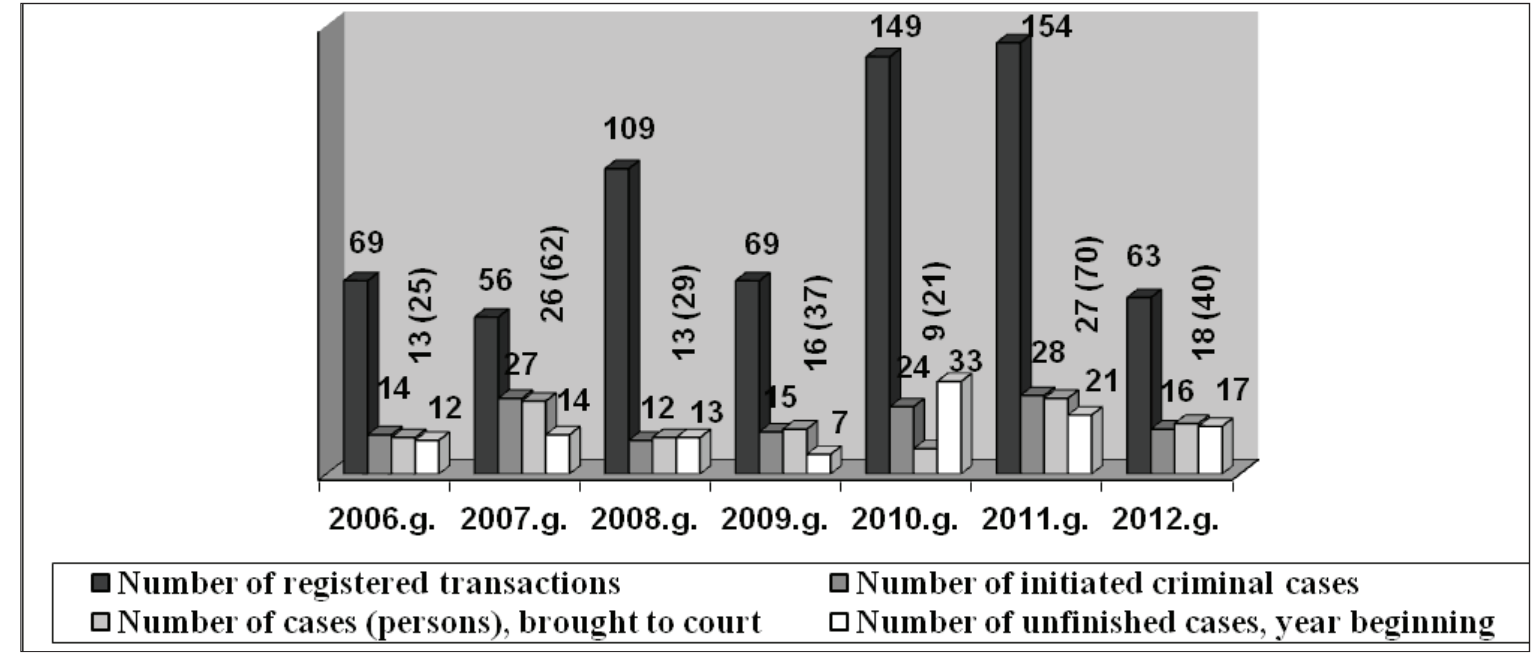

Figure 4. The results of performance of prosecution in AML/CTF in 2004-2012

Source: Composed by the author according to www.lrp.gov.lv

If to take into account that the level of grey economy in Latvia is evaluated at $21.1 \%$ of GDP, the losses for economy of Latvia are significant.

According to the results of two evaluations of AML/CTF efficiency in Latvia provided by Moneyval and WMF, Latvia conforms to the FATF recommendations (year 2006) and demonstrates the further progress (year 2009) but still faces the significant threat money laundering due to corruption, organized crime and non-residents' accounts and shall strengthen its risk-oriented approach to AML/CTF, increase in formation exchange and develop cooperation with law enforcement, facilitate efficiency of cases investigation and conviction of people guilty in financial crimes. 
The factors of high risk employed in LBS for money laundry are as follows:

- Majority transactions in dollars and a large proportion of non-resident deposits in Latvian banks from Eastern countries with high levels of capital flight and corruption.

- Prohibited practice of some banks to consult their own customers for AML / CFT.

- termination of the VEF Bank activities and Multibank problems as a result of the U.S. Treasury Department (2005) requisition.

- General Prosecutor's Office of Kazakhstan appeal for the assistance in connection with the transfer of stolen funds of "BTA Bank" to the offshore companies through commercial banks of Latvia (2011)

- ongoing investigation on charges of 6 Latvian banks to launder 19 million dollars in connection with the Magnitsky case.

- $\mathrm{UN}$ and the Organization of Global Witness suspicion in the use of the Latvian financial system by the Asian and the Central African regimes.

Thus, the regulation and verification of customers in Latvian banks are not at accepted levels, despite the positive trend of indicators and favorable evaluation by MONEYVAL and the IMF, for the Latvian regulators, there are significant challenges to improve the AML / CFT.

Evaluating the prospects of improvement of regulation in LBS, one can be sure that all essential changes in regulation, adopted in the EU, will be maximally widely adopted also in Latvia; however, their real efficiency will be still limited by level of economic development of the country and the character of implemented economic policy.

\section{Conclusion}

Effective BSL control is determined by the following terms and factors:

- the development level of financial and banking systems,

- the degree of compliance with international regulatory standards, considering national peculiarities of BSL,

- citizens legal culture,

- qualification and business ethics level of staff regulators and bank managers.

Regulation by itself cannot provides ufficient stability and efficiency of the modern financial and banking systems due to the complexity of the operations and methods of assessing risk, partially offset by the discipline of the market (Pillars-3 of Basel-2) via reducing thecost of funding for banks which are more transparent. Even with a good multi-level, outside the state system of supervision and control of any bank cannot be protected from intrudersevade the system.

Regulation essentially cannot provide sufficient stability and efficiency of performance of modern financial and banking systems due to the complexity of operations and risk evaluation methods that is partially compensated by market discipline (Pillars-3 of Basel-2) through reducing the cost of financing for more transparent banks. Even provided that there is a multilevel external state supervision and control system, no bank can be absolutely protected against law violators that circumvent this system.

The history of Latvian banking system in market condition is the evidence of specialists' conclusions that the key factor of financial stability and efficiency in market conditions remain the level of business ethics and professionalism of major shareholders and top management of the banks, but the main problem is the increase of the role of content approach to control in comparison with the formal approach.

The level of losses of population, business and economy overall due to inefficient national regulation is determined primarily by institutional factors that in turn are determined by social and economic priorities of national policy.

To improve the efficiency of regulation of Latvian banking system the following measures should be taken: 
- Increase of the role of content approach to control compared to formal approach based on Pillars-2 Basel-2.

- Strengthening of regulation of the banks that implement aggressive asset growth policy.

- Optimization of the amount and character of regulations introduced in the banks, based on costbenefit criteria, taking into account the specifics of the banks' activity.

- Increase of the role of sanctions of regulating bodies (Pillars-2) in case of insufficient transparency of banks' risks.

- Increase of the role of public organizations in the development of state bank regulation and clients protection policy for more reasonable distribution of losses in case of problems in the bank or in banking system overall.

\section{References}

Barltrop, C. J., McNaughton, D. (1994). Banking Institutions in Developing Markets. Interpreting Financial Statements, Vol. 2, с. 220. Москва.

Committee of experts on the evaluation of AML/FT, MONEYVAL. (2009). Annual report. Website: http://www.coe.int/t/ dghl/monitoring/moneyval/Activities/2009_AnnualReport_en.pdf

Enterprise Risk Management - Integrated Framework (COSO ERM). (2004). The Committee of Sponsoring Organizations of the Treadway Commission, September. Website: http://www.coso.org/documents/coso_erm_executivesummary.pdf

Finanšu un kapitāla tirgusko misijas likums: LR likums. (2000). Latvijas Vēstnesis, Nr. 230/232.

Framework for Internal Control Systems in Banking Organisations. (BCBS 40). Website: http://www.bis.org/publ/ bcbs40.pdf

Hipotēkubanka продают с убытками, но зарплата руководства растет. (2012). Website: http://www.kriminal.lv/ news/hipoteeku-banka-prodayut-s-ubytkami-no-zarplata-pre

Iekšèjās kontroles sistēmas izveides normatīvie noteikumi. (2012). Finanšu un kapitāla tirgus komisijas normatīvie noteikumi Nr. 233. Latvijas Vēstnesis, No. 176 (4779). Website: http://www.fktk.lv/texts_files/Noteikumu\%20 teksts_81112.pdf [07.11.2012].

Internal control - Integrated Framework. (1992). The Committee of Sponsoring Organizations of the Treadway Commission's. Website: http://www.coso.org/documents/Internal\%20Control-Integrated\%20Framework.pdf

Kredītiestāžu likums: LR likums. (2007). Latvijas Vēstnesis. Resurss aprakstīts 2007. g. 10. decembrī. Website: http:// www.lv.lv/index.php? $\operatorname{mode}=$ KDOC\&id $=37426$

Latvia Progress report. (2009). Second 3rd Round Written Progress Report Submitted to MONEYVAL, 9.12.2009. Website: http://www.coe.int/t/dghl/monitoring/moneyval/Evaluations/Progress\%20reports\%202y/ MONEYVAL\%282009\%2939-ProgRep2LAT en.pdf

LR Likums "Par noziedzīgi iegūtu līdzekḷu legalizācijas un terorisma finansēšanas novēršanu". Latvijas Republikas likums. Pieñemts Latvijas Republikas Saeimā 07.2008.; stājies spēkā 13.08.2008. LatvijasVēstnesis, Nr. 116 (3900) [30.07.2008].

Masharsky, A. (2010). The Features and Factors of Banking Crisis Developmant in Latvia. Proceeding of the International Conference. The Application of Sustainable Development: Critical Assessment. Klaipeda, p. 122-128.

Frost, S. (2004). The Bank Analyst's Handbook: Money, Risk and Conjuring Tricks. John Wiley \& Sons, 575 p. (Фрост, C. (2006). Настольная книга банковского аналитика. Деньги, риски и профессиональные приемы. Баланс Бизнес Букс, 672 с.).

Stiglitz, J. E. (2011). Freefall: America, Free Markets, and the Sinking of the World Economy, p. 389-510. (Стиглиц, Дж. Е. Крутое пике: Америка и новый экономический порядок после глобального кризиса. Мискжа: Эксмо).

The Banking Regulation Review. 3rd edition (published in May 2012, editor Jan Putnis). Law Business Research Ltd. Website: http://www.mourantozannes.com/media/721080/the_banking_regulation_review_-_jersey_chapter.pdf

Third Round Detailed Assessment Report on Latvia: Anti-Money Laundering and Combating the Financing of Terrorism, June 2007. Adopted by Moneyval at it's $20^{\text {th }}$ plenary meeting. (2006). Website: http://www.coe.int/t/dghl/ monitoring/moneyval/Evaluations/round3/MONEYVAL\%282006\%2919-I_Rep-LAT3_en.pdf

Van Greuning, H., Bratanovic, S. (2003). Analyzing and managing banking risk. A framework for assessing corporate governance and financial risk. The World Bank. Website: http://www-wds.worldbank.org/servlet/WDSContentServer?WDSP/IB/2000/03/21/000094946_00030305401492/Rendered/PDF/multi0page. 
pdf (Грюнинг, Х. ван, Брайович Братанович, С. (2003). Анализ банковских рисков. Система оценки корпоративного управления и финансовым риском. Пер. с англ „Мир”).

В Латвии отмывают деньги. (2010). Портал TVNET.lv. Website: http://rus.tvnet.lv/novosti/ekonomika/151959-v_ latvii_otmivajut_djengi.

Финансовый контролер: полностью защчитить банки от моченничества невозможно. (2011). Website: www. alex-lawyer.lv/zplds7.htm.

Кудрявцев, Н. (2013). Бюро адвоката Падвы: В Латвии у граждан России возникает «культурный шок». Портал о безопасности kriminal.lv. Website: http://www.kriminal.lv/news/byuro-padvy-v-latvii-u-grazhdan-rossii-kulyturn

Мосякин, А. (2013). «Базель ІІІ» отложили на будущее. Бизнес \& Балтия. Website: www.bb.lv/bb/all/11701/

Оленченко, В. (2012). Банковский сектор стран Балтии как фактор развития местных экономик. Портал «Перспективыl». Website: http://www.perspektivy.info/print.php?ID=164674

Ролдугин, В. (2010). Проблемь развития латвийской банковской системьл. Рига. Website: www.baltic-course. com/rus/kruglij_stol/?doc=24891や

Симановский, А. (2011). Три урока для надзора. Банковское обозрение, №1 (144). Website: http://www.bosfera.ru/ bo/2011/01/tri-uroka-dlya-nadzora

Система внутреннего контроля в банках: основы организации. (1998). Рекомендациии Базельского комитета по банковскому надзору № 40. Письмо Банка России от 10.07.2001 № 87-Т.

\section{LATVIJOS BANKŲ SISTEMOS VYSTYMOSI REGULIAVIMO VEIKSNIAI IR TENDENCIJOS}

Alexander Masharsky

Baltijos tarptautinè akademija (Latvija)

\section{Santrauka}

Šio straipsnio tikslas - išnagrinèti veiksnius, kurie padeda reguliuoti Latvijos bankų sistemą, ir nustatyti būdus, kaip šị reguliavimą gerinti. Pritaikius sisteminę lyginamają ir loginę duomenų apie Latvijos bankų sistemos vystymo reguliavimą skirtinguose etapuose analizę, nustatyta, kad pagrindiniai veiksniai yra verslo etikos lygis ir aukščiausio lygio vadovų bei bankų savininkų profesionalumas. Vienas pagrindinių būdų, kaip padidinti Latvijos bankų sistemos reguliavimo efektyvumą, - pereiti nuo formalios kontrolès prie i turini orientuotos kontrolès.

PAGRINDINIAI ŽODŽIAI: banku sistema, veiksniai, bruožai, reguliavimas, tendencijos.

JEL KLASIFIKACIJA: G 280, G010, G210 